\title{
IDENTIFIKASI KAWASAN KOTA LAMA GRESIK
}

\author{
Anak Agung Sagung Alit Widyastuty
}

\begin{abstract}
Abstrak
Keberadaan kota lama semakin memudar seiring dengan terdapatnya fenomena perubahan yang mengakomodasikan perkembangan yang terjadi. Kota lama Gresik terletak di sekitar alon - alon yang merupakan perkampungan kuno dan terletak di dalam kota. Seiring dengan perkembangannya perubahan fisik dan lingkungan ditandai dengan penambahan, perubahan dan pembongkaran bangunan bersejarah yang mencerminkan identitas kawasan dengan bangunan baru yang jauh berbeda dari karakteristik bangunan asli. Studi ini bertujuan untuk mendapatkan arahan pelestarian kawasan kota lama dengan terlebih dahulu mengetahui tingkat perubahan fisik dan lingkungan yang terjadi dengan membandingkan kondisi dulu dengan kondisi saat ini. Hasil studi ini menunjukkan bahwa kawasan kota lama Gresik dalam perkembangannya semakin mengalami perubahan fisik maupun lingkungan mengakibatkan kaburnya / hilangnya identitas kota. Terjadinya perubahan fisik dan lingkungan tersebut di indikasikan karena factor fisik (pengguna lahan dan kondisi bangunan) dan factor non fisik (ekonomi, social budaya dan masyarakat sekitar dan factor hokum) terjadinya perbedaan infrastruktur kawasan, terjadinya perubahan fungsi bangunan, belum terdapatnya peraturan bangunan / lingkungan serta terjadinya perbedaan struktur pertumbuhan ekonomi kawasan serta kurangnya pengetahuan dan keperdulian masyarakat akan sejarah dan kebudayaan yang dimiliki merupakan beberapa factor yang menjadi penyebab terjadinya perubahan fisik dan lingkungan di kawasan kota lama Gresik.
\end{abstract}

Kata Kunci : Kota Lama Gresik, identitas kota, pelestarian kota.

\section{PENDAHULUAN}

Gresik

secara administrasi merupakan wilayah daerah tingkat II yang dikepalai oleh seorang Bupati di bawah pemerintahan propinsi Jawa Timur. Dengan lokasi yang terletak di pesisir pantai, kota Gresik memiliki potensi yang cukup besar bagi pengembangan wilayahnya.

Apabila ditinjau dari kurun perjalanan sejarah, kota Gresik pernah mengalami masa kejayaan yang menjadikannya sebagai pusat kegiatan yang multi dimensi baik di bidang perdagangan, pendidikan, keagamaan dan pemerintahan serta masyarakat dengan kultur yang heterogen yang merupakan pembauran berbagai etnis seperti Cina, India, Arab dan Melayu dengan penduduk setempat.

Pada masa ini pola kehidupan dan tatanan perkotaan sudah tertata dengan baik sesuai dengan lokasi masyarakat pada masa itu. Kota berkembang dengan pesat namun tetap dapat melayani dan memenuhi kebutuhan masyarakat baik dari sarana dan prasarana kota. Bahkan pemanfaatan lahannya sesuai dengan kebutuhan berdasarkan lokasi kegiatan, bentuk bangunan yang mencerminkan si pemilik bangunan serta ruang - ruang public yang dimanfaatkan sesuai dengan rencana.
Sebagai kota pelabuhan Gresik memiliki asset yang sangat besar dalam hubungannya dengan daerah - daerah luar, hal ini berperan dalam tatanan perencanaan kota maupun bentuk bangunan yang ada yang masih terlihat sampai saat ini meskipun sebagian dari bangunan - bangunan itu bahkan tidak dihuni bahkan tidak dirawat sama sekali.

Melihat kondisi masa lalu yang gemilang, sangat bertolak belakang dengan keadaan Gresik pada masa ini dimana pelabuhan yang dulunya ramai oleh pendatang dan pedagang bahkan berkesan menjadi lokasi yang rawan dan sepi, demikian juga pada pemanfaatan lahan kota dan bangunan bangunan baru yang bermunculan seolah tanpa kendali.

Sehingga dengan melihat kejayaan masa lalu dan keterpurukan masa kini diharapkan akan ditemukan gambaran bagi perencanaan kota Gresik untuk masa yang akan datang. Fenomena - fenomena yang terjadi saat ini yang pertama telah terjadi peningkatan penggunaan lahan terutama

\footnotetext{
*) Dosen Perencanaan Wilayah dan Kota (PWK) Universitas PGRI Adi Buana Surabaya
} 
pada daerah Lumpur (sekitar jalan Sindujoyo) berupa bangunan fungsi - fungsi dengan peruntukan permukiman campuran (lebih didominasi oleh masyarakat pendatang ras Melayu), kedua fungsi bangunan - bangunan kuno yang sekarang ada, sebagian besar adalah milik perorangan dan difungsikan sebagai bangunan niaga (perdagangan dan jasa), namun sebagian lagi telah mengalami pergeseran fungsi seperti sarang burung wallet. Hal ini terlihat pada bangunan - bangunan jl. Nyai Ageng Pinatih dan Jl. Nyai Ageng Arem - Arem dan ketiga adanya perubahan fungsi ruang public yang berupa bangunan kuno untuk aktivitas pemerinth menjadi bangunan kosong atau bahkan menjadi perumahan untuk kalangan pemerintahan, misalnya rumah Bupati dan rumah Pembantu Bupati

\section{Rumusan masalah}

1. Bagaimana arahan pengembangan bangunan kuno dan lingkungannya dapat seoptimal mungkin dirasakan kehadirannya oleh masyarakat, sehingga mampu meningkatkan nilai dari keberadaannya.

2. Bagaimana mengoptimalkan bangunan - bangunan ruang public kuno agar dapat dirasakan kegunaannya sebagai bangunan sarana dan prasarana kota

3. Sejauhmana perubahan dan dampak pergeseran yang terjadi baik dari segi fungsi maupun bentuknya yang terjadi akibat pengaruh - pengaruh baik dari luar maupun dari dalam kota Gresik sendiri terhadap perkembangan kota.

\section{Tinjauan Pustaka}

1. Tinjauan Teori Pertumbuhan Kota Ada beberapa teori pertumbuhan kota yang dapat digunakan dalam penelitian ini antara lain :
a. Teori Konsentris
b. Teori Poros
c. Teori Lokasi

2. Tinjauan Dampak Pertumbuhan Kota Menurut pandangan Lewis Mumford (1976) meskipun perkampungan permanen baru dimulai sejak zaman Neolitik namun kebiasaan untuk berkumpul untuk penyelenggaraan upacara bersama - sama tampaknya telah dimulai sejak periode awal : dan seluruh masyarakatnya telah hidup dalam daerah - daerah yang sangat terpencar sampai saat ini. Pola garis kota baik sebagai bentuk luar manusiapun sebagai pola kehidupan ke dalam, bisa ditemui di tempat - tempat berkumpul semacam itu. Tinjauan Ruang public Kota. Ruang kota adalah ruang - ruang geometris yang dibatasi oleh elevasi - elevasi sebuah ruang luar yang terbuka, bebas halangan sehingga memungkinkan pengaliran segala macam pergerakan dan bersifat public. Ruang ini pada dasarnya terdiri dari dua macam : jalan (street) dan lapangan (square), (Andy Siswanto, 1997)

3. Pengertian Kota Lama

Kawasan kota lama merupakan bagian elemen fisik dari sebuah kota yang memiliki potensi untuk dikembangkan dalam membentuk karakteristik sebuah kota. Karena merupakan kawasan yang memiliki nilai sejarah dan ekonomi untuk pengembanan kota. Kawasan beserta bangunan - bangunan kuno merupakan suatu eprwuudan bentuk nyata peninggalan menjadi bukti fisik kekayaan budaya bangsa.

4. Pusaka (cagar Budaya)

Pengertian Cagar Budaya

Dalam peraturan daerah kota Surabaya no. 5 tahun 2005 tentang pelestarian bangunan dan atau lingkungan membagi Cagar budaya menjadi 2 jenis

1) Bangunan cagar budaya :

Bangunan buatan manusia yang berumur sekurang - kurangnya 50 tahun yang mewakili masa gaya yang khas dan mewakili masa gaya sekurang - kurangnya 50 tahun serta dianggap mempunyai nilai penting bagi sejarah, ilmu pengetahuan dan kebudayaan.

Penentuan bangunan cagar budaya ditetapkan berdasarkan criteria:Umur, Estetika, Kejamakan, Kelangkaan, Nilai sejarah, Memperkuat kawasan, Keaslian, Keisimewaan, tengeran

2) Lingkungan cagar budaya :

Adalah kawasan di sekitar atau di sekeliling bangunan cagar budaya yang diperlukan untuk pelestarian bangunan cagar budaya dan atau kawasan tertentu yang berumur sekurang - kurangnya 50 (lima puluh) tahun, serta dianggap mempunyai nilai penting bagi sejarah, ilmu pengetahuan dan kebudayaan.

Penentuan lingkungan cagar budaya ditetapkan berdasarkan criteria 
:Umur, ,Keaslian, Nilai sejarah, Kelangkaan, Ilmu pengetahuan

5. Pelestarian Kota

Beberapa batasan pengertian tentang istilah - istilah yang disepakati dalam Piagam Burra antara lain :

1) Konservasi

Adalah segenap proses pengelolaan suatu tempat agar makna cultural yang dikandungnya terpelihara dengan baik. Konservasi dapat meliputi seluruh kegiatan pemeliharaan dan sesuai engan situasi dan kondisi setempat dapat pula mencakup preservasi, restorasi, rekonstruksi, adaptasi dan revitalisasi

2) Preservasi

Adalah pelestarian suatu tempat persis seperti keadaan aslinya, tanpa ada perubahan, termasuk upaya pencegahan penghancuran.

3) Restorasi/rehabilitasi

Adalah mengembalikan suatu tempat ke keadaan semula dengan menghilangkan tambahan tambahan dan memasang komponen semula tanpa menggunakan bahan baru.

4) Rekonstruksi

Adalah mengembalikan suatu tempat semirip mungkin dengan keadaan semula sejauh yang diketahui dengan menggunakan bahan lama maupun bahan baru.
5) Adaptasi / Revitalisasi

Adalah merubah tempat agar dapat digunakan untuk fungsi yang lebih sesuai. Yang dimaksud dengan fungsi yang lebih sesuai dengan kegunaan yang tidak menuntut perubahan draktis atau yang hanya memerlukan sedikit dampak minimal.

6) Demolisi

Adalah penghancuran atau pengrombakan suatu bangunan yang sudah rusak atau membahayakan.

Klasifikasi atau jenis pelestarian lainnya

1) Gentifikasi

Upaya perbaikan kualitas kota dengan perbaikan kualitas lingkungan tetapi tanpa membuat perubahan penting pada struktur fisik bangunan, melalui rehabilitasi, renovasi

2) Renovasi

Perubahan kembali bangunan bangunan lama melalui perubahan fungsi/kegiatan dalam bangunan dengan tidak merubah penampilan fisik bangunan

Mengenai tingkat perubahan yang diakibatkan oleh masing - masing kategori kegiatan tersebut dapat dilihat dalam tabel 1.1 sebagai berikut

Tabel 1.1 : Kategori Kegiatan Konservasi

\begin{tabular}{llcccc}
\hline \multirow{2}{*}{ No } & \multicolumn{1}{c}{ Kegiatan } & \multicolumn{4}{c}{ Tingkat perubahan } \\
\cline { 3 - 6 } & Konservasi & $*$ & $*$ & $*$ & $*$ \\
\hline 1 & Preservasi & - & - & - & - \\
2 & Restorasi & - & $*$ & $*$ & - \\
3 & Rekonstruksi & - & - & $*$ & $*$ \\
4 & Adaptasi/revitalisasi & - & $*$ & - & - \\
5 & Demolisi & - & - & - & $*$ \\
6 & & & & &
\end{tabular}

\section{METODOLOGI PENELITIAN}

Pendekatan penelitian digunakan dalam penelitian adalah pendekatan positivism yang bersumber pada fakta empiris. Jenis penelitian ini adalah penelitian deskriptif dengan metode eksplorasi. Analisis deskriptif dilakukan pada penyusunan hasil pengisian kuisioner dan diharapkan dapat dijadikan dasar preskriptif.

1. Metode Pengumpulan Data
Metode pengumpulan data adalah cara yang digunakan oleh peneliti uyntuk memperoleh data yang dibutuhkan dalam rangka mencapai tujuan dan sasaran penelitian. Proses pengumpulan data dilakukan dengan menggunakan teknik survey data sekunder dan primer. Pengumpulan data sekunder bersumber dari dokumen perencanaan wilayah, BPS Surabaya, Dinas pendidikan dan kebudayaan dan 
sumber - sumber lainnya. Kemudian pengumpulan data primer bersumber hasil pengamatan, penyebaran kuisioner dan wawancara terhadap masyarakat yang tinggal disekitar kawasan kota lama dan pakar.

2. Variabel Penelitian

Variable dalam penelitian ini antara lain : bentuk fisik bangunan (status kepemilikan, usia bangunan, kondisi bangunan, perubahan selera pemilik, infrastruktur), social budaya (pengetahuan masyarakat), ekonomi dan hukum.

3. Teknik sampling

Sebelum dilakukan survey penelitian maka dilakukan survey pendahuluan sebesar 25 responden secara acak untuk mengetahui jumlah sampel minimum yang harus diambil. Adapun pengambilan sampel yang digunakan pada penelitian ini melalui metode pengambilan sampel acak sederhana. Metode ini digunakan untuk penentuan sampel konsumen, dimana untuk memilih sampel dari populasi dengan cara sedemikian rupa sehingga setiap anggota populasi memiliki peluang yang sama besar untuk diambil sebagai sampel. Populasi merupakan populasi terhitung dengan metode pengambilan sampel secara acak dimana populasi adalah homogeny. Berikut rumus perhitungannya

$$
n=N /\left(1+N \times e^{2}\right)
$$

Dimana

$$
\begin{aligned}
& n=\text { jumlah responden } \\
& \mathrm{N}=\text { jumlah populasi } \\
& \mathrm{e}=\text { besarnya toleransi yang }
\end{aligned}
$$

digunakan $(0,1)$

Dengan demikian sampel total responden ( $\mathrm{n}$ ) pada wilayah penelitian adalah sebanyak

$$
\begin{gathered}
\mathrm{n}=1406 /(1+1406 \times 0,01) \\
=99 \text { responden }
\end{gathered}
$$

4. Teknik Pengolahan dan Analisa Data Teknik analisa yang digunakan dalam penelitian ini adalah kualitatif. Analisa kualitatif bertujuan untuk mengetahui factor - factor yang menjadi pertimbangan dalam pelestarian kawasan kota lama Gresik. Teknik analisa yang digunakan adalah teknik scoring. Hasil dari teknik scoring yang

\begin{abstract}
bersifat kuantitatif di deskripsikan secara kualitatif guna mencari penggolongan kawasan atas dasar urgensi kepentingan pelestarian benda atau kawasan bersejarah di kota lama Gresik, setelah diketahui criteria criteria utama dalam pelestarian kawasan kota lama.
\end{abstract}

\section{ANALISA DAN PEMBAHASAN \\ Identifikasi perubahan fisik dan lingkungan di kawasan kota lama Gresik}

Untuk mengetahui tingkat perubahan bangunan dan lingkungan di kawasan kota lam Gresik, yaitu dengan menganalisi perubahan dari karakteristik bangunan dan lingkungan kawasan dengan kondisi sekarang.

Tipe perubahan fisik dan lingkungan di Kawasan kota lama Gresik dapat di jelaskan seperti di bawah ini :

\section{Kawasan Kampong Pecinan}

Karakteristik Kawasan

- Merupakan perkampungan lama dengan fungsi bangunan yaitu rumah tinggal etnis Cina

- Karakteristik Cina/Tionghoa

- Karakteristik bangunan menggunakan arsitektur Cina, yakni atap bangunan yang menyerupai bangunan klenteng, warna yang mencolok (merah) dan bau dupa yang khas di sekitar kawasan pecinan

- Karakteristik adat berupa pengadaan barongsai dan acara sembahyang pada hari - hari tertentu

- Karakteristik penduduk sebagai pedagang.

\section{Gambaran Eksisting}

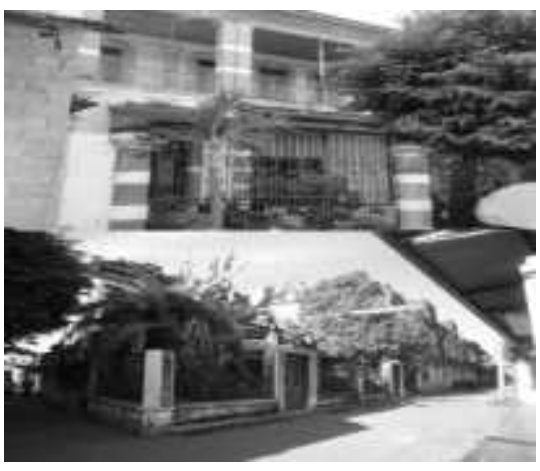

Karakteristik Sekarang

- Merupakan perkampungan etnis Jawa dan Madura 
- Karakteristik masyarakat Jawa dan Madura

- Sudah tidak diketemukan lagi kegiatan sembahyang di Klenteng dan kegiatan barongsai sebagai acara perayaan hari besar.

- Tidak ada aktivitas di tempat peribadatan (Klenteng)

- Karakteristik bangunan berupa atap yang masih menyerupai bangunan Klenteng namun terdapat perubahan warna

- Penduduk berprofesi sebagai pengrajin kue dan makanan

\section{Kawasan Kampung Arab}

\section{Karakteristik Kawasan}

- Merupakan perkampungan lama (kuno) dengan fungsi bangunan yaitu rumah tinggal etnis Arab.

- Karakteristik bangunan, teras terbuka dengan tiang penyangga yang tinggi dan teras terbuka

- Karakteristik lingkungan kuldesac (tertutup)

- Tradisi pengrajin sarung tenun dan kopyah serta pengrajin kaligrafi

- Tradisi Qudrah pada hari - hari besar Islam

\section{Gambaran Eksisting}

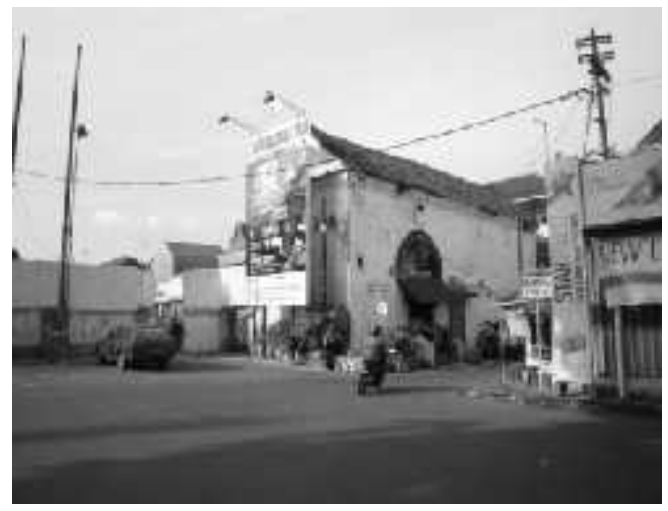

\section{Karakteristik Sekarang}

- Merupakan perkampungan dengan fungsi bangunan perumahan dan perdagangan dan jasa

- Karakteristik bangunan berupa atap, teras dan keranda $50 \%$ telah berubah dari aslinya karena proses renovasi

- Karakteristik lingkungan masih dalam kondisi asli yakni (lingkungan yang tertutup)

- Karakteristik wilayah berupa pengrajin sarung tenun dan kopyah serta kaligrafi
- Tradisi Qudrah di lingkungan masyarakat sekitar pada hari Ramadhan

3. Kawasan Kampong Kemasan Karakteristik Kawasan

- Merupakan perkampungan lama (kuno) dengan fungsi bangunan yaitu tempat tinggal etnis Jawa

- Karakteristik bangunan bergaya Eropa-Cina dengan ciri khas berupa tiang-tiang penyangga yang besar dan bangunan berlantai dua dan atap bangunan terdapat ukir ukiran dan warna yang mencolok (merah). Bangunan atas bersifat tertutup dengan jendela-jendela yang besar yang menyerupai pintu.

- Karakteristik masyarakat berupa terdapat ikatan kerabat dalam satu lingkungan atau kampong

- Karakteristik masyarakat berupa pengrajin emas

\section{Gambaran Eksisting}

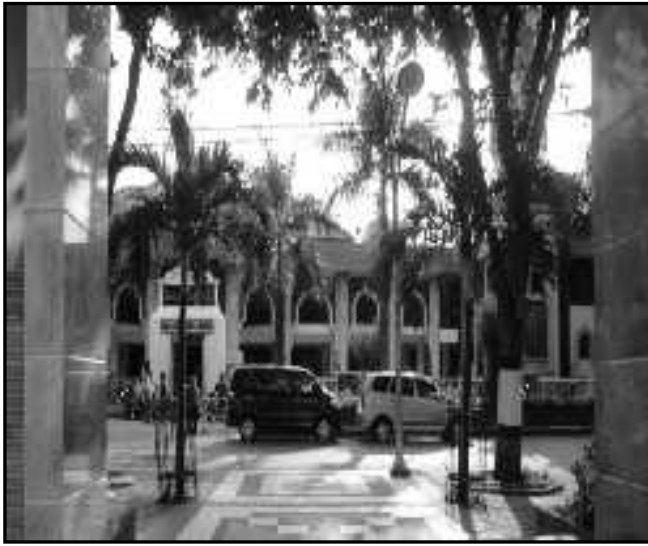

\section{Karakteristik Sekarang}

- Merupakan perkampungan lama (kuno) dengan fungsi sarang burung wallet dan permukiman

- Karakteristik bangunan dan lingkungan masih terjaga aslinya walau dalam kondisi tidak terawatt (kotor)

- Karakteristik bangunan dan lingkungan berupa warna mencolok sudah mulai pudar seiring dengan usia bangunan dan tidak adanya perawatan

- Tidak ada ikatan kerabat dalam satu lingkungan (perkampungan)

- Karakteristik berupa pengusaha/pegawai yang tinggal di luar kota 
4. Kawasan Kampong Kepatihan

\section{Karakteristik Kawasan}

- Merupakan perkampungan lama (kuno) dengan fungsi bangunan yakni tempat tinggal

- Karakteristik bangunan berupa bangunan pendopo dengan teras yang lebar, tiang penyangga yang besar

- Karakteristik penduduk merupakan para pegawai pemerintah.

\section{Gambaran Eksisting}

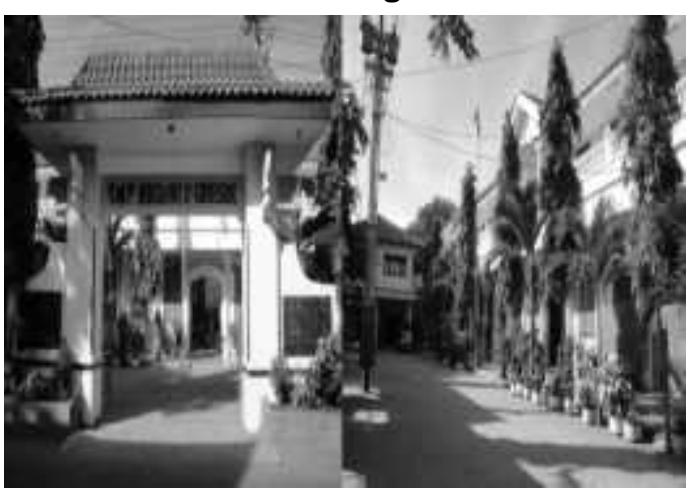

Karakteristik Sekarang

- Merupakan perkampungan lama (kuno) dan berungsi sebagai tempat tinggal

- Karakteristik bangunan, sudah tidak ditemukan lagi teras yang lebar, atap bangunan masih berbentuk pendopo, bagian depan direnovasi sehingga tidak terdapat atap penyangga yang besar.

- Karakteristik masyarakat yang sudah berubah menjadi pengrajin dan pedagang.

\section{Kawasan Kampung Pakelingan}

\section{Karakteistik Kawasan}

- Merupakan perkampungan lama (kuno) dengan fungsi bangunan yaitu tempat tinggal.

- Karakteristik bangunan merupakan gabungan antara Eropa dan Cina berupa atap menara - menara kecil terdapat keranda pada bagian depan rumah, terdapat ukir - ukiran pada bagian teras depan.

- Karakteristik masyarakat berupa pedagang

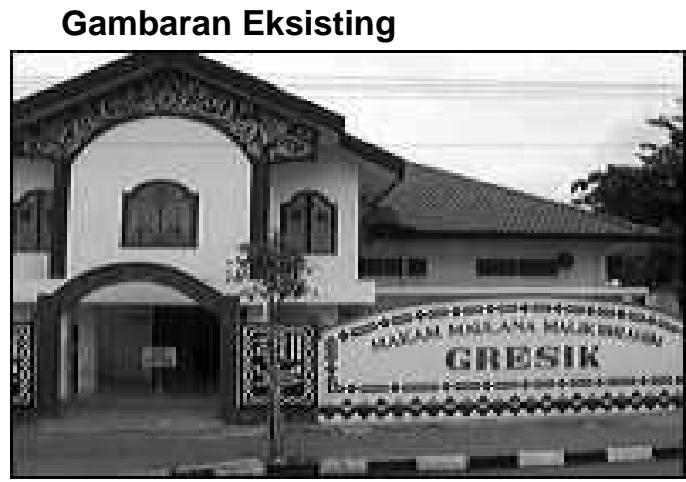

\section{Karakteristik Sekarang}

- Merupakan perkampungan lama (kuno) dengan fungsi sebagai tempat tinggal.

- Karakteristik bangunan lama masih terlihat pada atap yang terdapat menara - menara kecil, sedangkan keranda pada depan rumah masih dijumpai pada beberapa rumah dengan penambahan ornament depan rumah

- Karakteristik masyarakat berupa pengrajin dan pedagang.

6. Kawasan Kampong Pekauman Karakteristik Kawasan

- Merupakan perkampungan lama (kuno) dengan fungsi bangunan yakni tempat tinggal.

- Karakteristik bangunan merupakan bangunan dengan dua lantai bersifat terbuka terdapat ukir - ukiran pada bagian atap bangunan dan terdapat keranda pada bagian depan rumah dan atap yang berbentuk melengkung

- Karakteristik masyarakt berupa pengrajin

\section{Gambaran Eksisting}

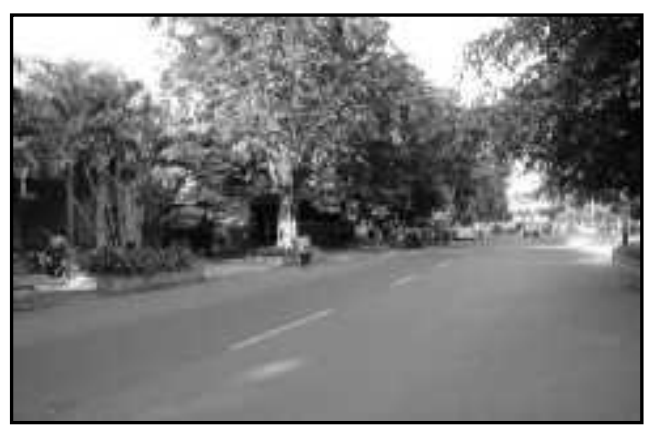




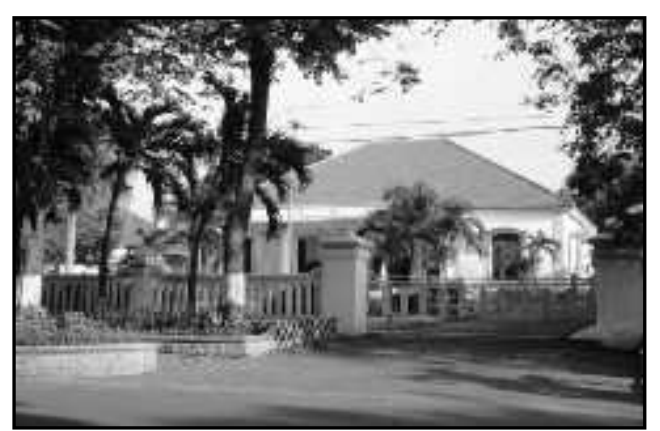

\section{Karakteristik Sekarang}

- Fungsi bangunan masih berupa perumahan (tempat tinggal)

- Karakteristik bangunan masih berupa bangunan dengan dua lantai, masih terdapat ukir - ukiran pada atap, terdapat penambahan bangunan berupa pagar, sehingga bersifat tertutup dan bagian atap masih berbentuk melengkung.

- Karakteristik masyarakat berupa pedagang.

\section{Kawasan Jalan Samandhudi}

\section{Karakteristik Kawasan}

- Merupakan bentukan koridor dengan fungsi bangunan sebagai rumah/tempat tinggal etnis Jawa

- Karakteristik bangunan berupa atap berbentuk lengkung, bagian depan terdapat teras yang lebar dan bersifat terbuka terdapat tiang - tiang penyangga, jendela berukuran seperti pintu.

- Karakteristik bangunan terdiri dari dua lantai dengan penyangga atap (tiang) yang tinggi dan ukir - ukiran pada atap bangunan

- Karakteristik masyarakat berupa pengrajin kopyah dan sarung

\section{Gambaran Eksisting}

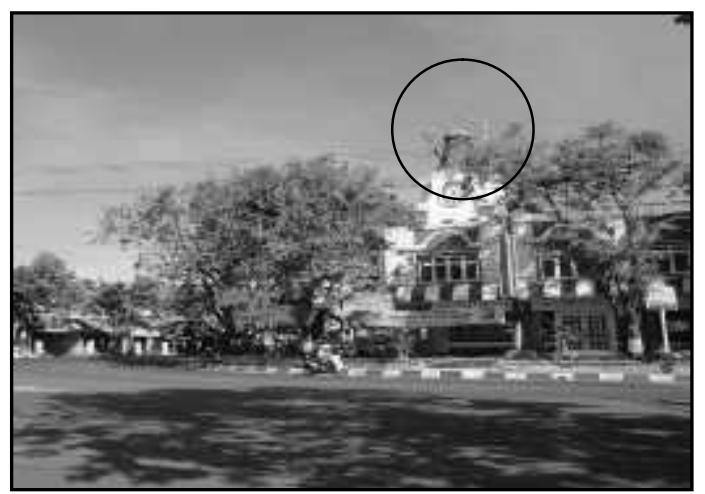

\section{Karakteristik Sekarang}

- Dominasi bangunan berupa perdagangan dan jasa

- Ketinggian dua lantai, bagian bawah merupakan took dan bagian atas berfungsi sebagai tempat tinggal, atap berbentuk bangunan modern (tidak ditemukan lagi atap yang melengkung, serta jendela yang berukuran seperti pintu )

- Karakteristik masyarakat berupa pedagang.

\section{Kawasan Jalan K.H Kholil Karakteristik Kawasan}

- Merupakan bentukan koridor dengan fungsi bangunan sebagai tempat tinggal dan fasilitas umum berupa sekolah rakyat.

- Karakteristik bangunan lama terdapat keranda di bagian depan rumah dan terdiri dari dua lantai, bagian samping atap terdapat ukir ukiran, yang merupakan ciri dari perkampungan Srab serta sebagian besar bangunan yang terdiri dari bahan kayu.

- Cirri khas lingkungan, terdapat taman pada bagian depan rumah

- Karakteristik masyarakat berupa pedagang

\section{Gambaran Eksisting}

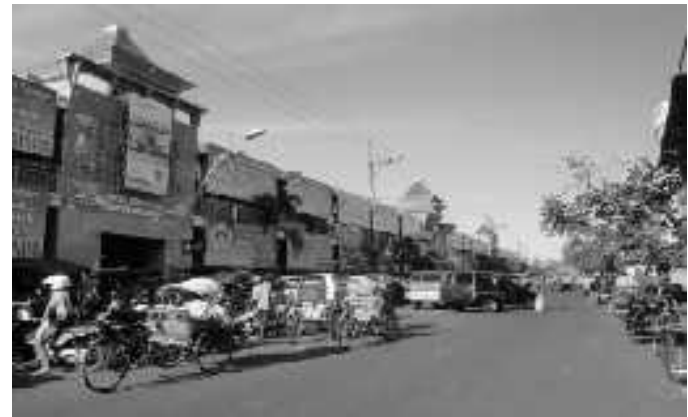

\section{Karakteristik Sekarang}

- Fungsi bangunan sebagian besar merupakan perdagangan dan jasa, tempat tinggal dan perkantoran.

- Karakteristik bangunan pada beberapa rumah masih mencirikan bangunan lama, tapi dalam keadaan tidak terawatt 
9. Kawasan Jalan Pahlawan

Karakteristik Kawasan

- Merupakan bentkan koridor dengan fungsi bangunan sebagai rumah/tempat tinggal etnis Jawa.

- Karakteristik bangunan berupa atap berbentuk melengkung bagian depan terdapt teras yang lebar dan bersifat terbuka terdapat tiang - tiang penyangga jendela yang berukuran seperti pintu

- Karakteristik bangunan terdiri dari dua lantai dengan penyangga atap (tiang) yang tinggi dan ukiran - ukiran pada atap bangunan

\section{Gambaran Eksisting}
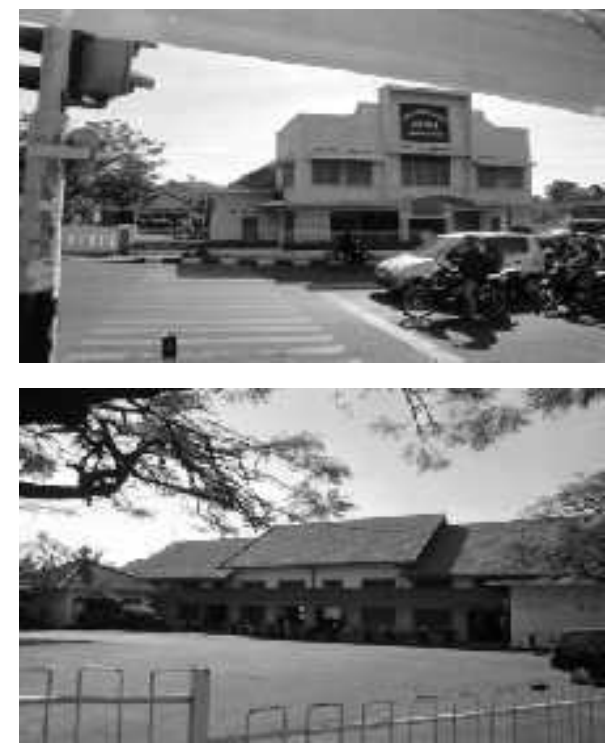

\section{Karakteristik Sekarang}

- Dominasi bangunan berupa perdagangan dan jasa

- Ketinggian satu lantai dengan fungsi sebagai took dan bagian atas berfungsi sebagai tempat tinggal atap berbentuk bangunan modern (tidak ditemukan lagi atap yang melengkung serta jendela yang berukuran seperti pintu)

- Karakteristik masyarakat berupa pedagang

Berdasarkan cirri dari penggolongan atau pengelompokkan di atas maka kawasan kota lama Gresik dapat dikelompokkan menjadi :

1. Kawasan dengan kondisi sedang, yang ditunjukkan perubahan sebagian bangunan atau kawasan, yakni kampong Arab, kampong Kemasan dan kampong Kepatihan dan Kampung Pecinan

2. Kawasan dalam kondisi buruk karena banyak mengalami perubahan adalah koridor jalan Pahlawan, Koridor jalan K.H Kholil, kampong Kemuteran dan Koridor jalan Samanhudi.

3. Sedangkan untuk tipe A yakni kawasan yang masih dalam kondisi baik, tidak terdapat di kawasan penelitian karena rata - rata bangunan dan lingkungan sudah mengalami perubahan, baik itu karakteristik bangunan, lingkungan maupun karakteristik masyarakatnya

Tabel 5.3 : Arahan pelestarian kawasan kota lama pada kawasan dengan tipe B

\begin{tabular}{|c|c|c|}
\hline No & $\begin{array}{c}\text { Kawasan } \\
\text { (Daerah) }\end{array}$ & Arahan \\
\hline 1 & $\begin{array}{l}\text { Kampong } \\
\text { Arab, } \\
\text { Kampung } \\
\text { Kemasan, } \\
\text { Kampung } \\
\text { Kepatihan } \\
\text { dan } \\
\text { Kampung } \\
\text { Pekauman } \\
\text { dan } \\
\text { Kampung } \\
\text { Pecinan }\end{array}$ & $\begin{array}{l}\text { Mempertahankan bangunan dan lingkungan sekitar dengan pembuatan desain } \\
\text { kawasan yang sesuai dengan kawasan sekitar terkait dengan bahan atau } \\
\text { ornament, warna dan desain arsitektural } \\
\text { Penambahan fungsi atau adaptive reuse yang mengacu kepada UU no. } 5 \text { tahun } \\
1992 \text { dan untuk kawasan kota lama Gresik yakni daerah pariwisata berupa } \\
\text { pariwisata religi pariwisata kuliner dan pariwisata kampong kuno } \\
\text { Mempertahankan dan mengendalikan bangunan dan lingkungan dengan } \\
\text { penambahan bangunan baru dengan pembatasan bangunan yang boleh dibangun } \\
\text { adalah bangunan public dan disesuaikan dengan karakteristik kawasan. } \\
\text { Di dalam persil atau lahan bangunan bersejarah dimungkinkan adanya bangunan } \\
\text { tambahan yang menjadi satu kesatuan yang utuh dengan bangunan utama dan } \\
\text { direncanakan dengan penuh kepekaan sehingga tidak merubah karakteristik asli } \\
\text { dari bangunan itu sendiri } \\
\text { Bangunan yang dalam kondisi berubah fungsi menjadi sarang burung wallet, } \\
\text { sehingga menjadi kotor dan tidak terawat diarahkan untuk mempertahankan } \\
\text { langgam atau gaya bangunan semula berupa tampilan luar dan atap bangunan } \\
\text { Pelestarian bangunan dan lingkungan kawasan bersejarah dengan pemberian }\end{array}$ \\
\hline
\end{tabular}


keringan pajak PBB, kemudahan dalam balik nama, penghargaan dengan imbalan bantuan dana dalam perawatan bangunan apabila mau melestarikan bangunan dan lingkungan yang dimiliki

Untuk bangunan yang telah berubah sebagian dikarenakan terjadinya perubahan fungsi sehingga merusak karakteristik kawasan sekitar dilakukan penertiban ijin sehingga bangunan yang telah berubah fungsi dan fisik menjadi kawasan perdagangan tanpa melalu perubahan ijin dikenakan sanksi atau denda

Pemberian roh kawasan yakni dapat berupa :

- Pengadaan agenda kegiatan, berupa pagelaran seni adat tradisional pada hari - hari tertentu, seperti hari kemerdekaan RI, hari besar Islam dan lain sebagainya.

- Pelestarian karakteristik kegiatan berupa kerajinan sarung tenun, kopyah dan seni kaligrafi di kampong Arab

- Pengadaan kegiatan bazaar atau stan untuk penjualan produk - produk yang mencirikan local, seperti sarung, kopyah dan kaligrafi

Tabel 5.4 : Arahan pelestarian kawasan kota lama pada kawasan dengan tipe C

\begin{tabular}{|c|c|c|}
\hline No & $\begin{array}{c}\text { Kawasan } \\
\text { (Daerah) }\end{array}$ & Arahan \\
\hline 1 & $\begin{array}{l}\text { Koridor jalan } \\
\text { Samanhudi, } \\
\text { koridor jalan } \\
\text { K.H Kholil } \\
\text { koridor jalan } \\
\text { pahlawan, } \\
\text { koridor jalan } \\
\text { Basuki } \\
\text { Rahmat }\end{array}$ & $\begin{array}{l}\text { Mempertahankan bangunan dan lingkungan yang masih tersisa dengan pembuatan } \\
\text { desain kawasan berupa pengaturan massa, KLB dan ketinggian bangunan yang } \\
\text { menunjang bangunan/kawasan bersejarah sekitar sebagai zona penyangga yakni } \\
\text { kawasan yang sudah banyak berubah baik fisik maupun fungsi namun masih } \\
\text { mendukung melindungi dan menandakan karakteristik kawasan } \\
\text { Penambahan fungsi atau adaptive use yang mengacu pada UU no. } 5 \text { tahun } 1992 \\
\text { yakni daerah yang menunjang kegiatan sekitar, yakni daerah perdagangan dan jasa } \\
\text { yang bersifat local dan menjual barang - barang yang merupakan cirri khas daerah } \\
\text { setempat. } \\
\text { Penambahan bangunan baru hanya dapat dilakukan untuk kepentingan public dan } \\
\text { disesuaikan dengan karakteristik bangunan sekitar } \\
\text { Pemberian insentive berupa kemudahan perijinan, dalam bentuk ijin usaha dan IMB } \\
\text { untuk bangunan yang mengalami perubahan fungsi dan fisik namun masih } \\
\text { mengindahkan bangunan lama dan menyesuaikan dengan karakteristik kawasan } \\
\text { sekitar sebagai bentuk pengendalian perubahan fisik dan lingkungan } \\
\text { Pengendalian dalam perubahan fisik dan lingkungan dilakukan dalam bentuk } \\
\text { pemberian disinsitiv yakni berupa penertiban ijin (ijin usaha dan IBM) } \\
\text { Pemberian roh kawasan yakni dapat berupa: } \\
\text { - Pengadaan agenda kegiatan, berupa pagelaran seni adat istiadat pada hari - } \\
\text { hari tertentu, seperti hari kemerdekaan RI hari besar Islam dan lain sebagainya } \\
\text { - Pengadaan kegiatan bazaar atau stan untuk penjualan makanan asli untuk } \\
\text { penjualan makanan asli yang mencirikan local, jajanan pudak, nasi krawu dan } \\
\text { lain sebagainya } \\
\text { Pengadaan festival Grissee tempoe doeloe yang menonjolkan karakteristik } \\
\text { kawasan yang dimiliki }\end{array}$ \\
\hline
\end{tabular}

\section{KESIMPULAN}

Kesimpulan yang dapat diambil dari penelitian mengenai arahan pelestarian kawasan kota lama Gresik adalah bahwa perubahan fisik dan lingkungan di kawasan kota lama Gresik dapat diidentifikasi menjadi dua tipe perubahan yakni :

1. Kawasan dengan tipe $B$ yakni kawasan yang telah mengalami sebagian perubahn bangunan atau kawasan, yang ditandai dengan masih terdapatnya karakteristik kawasan berupa fungsi kawasan dan bangunan, berubahnya fisik bangunan yakni dalam hal penambahan ornament berupa sosoran, perubahan dalam warna cat, penambahan bangunan depan naming masih mencirikan karakteristik kawasan, serta masih terdapatnya karakteristik masyarakat berupa adat atau tradisi. Tipe kawasan dengan kriteria ini tersebut adalah kampong Arab, kampong Kemasan, kampong Kepatihan dan kampong Pekauman. 
2. Kawasan dengan tipe $\mathrm{C}$ yakni kawasan yang dalam kondisi buruk karena banyak mengalami perubahan baik fisik maupun lingkungan. $\mathrm{Hal}$ ini diindikasikan dengan telah berubahnya karakteristik kawasan, berubahnya karakteristik fisik yakni bangunan dan

karakteristik masyarakat $\begin{array}{r}\text { berupa } \\ \text { adat/tradisi. } \\ \text { Kondisi } \\ \text { tiidentifikasebut }\end{array}$
Samanhudi, kordapat di koridor jalan
koridor jalan Pahlawan, $\mathrm{KH}$ Kholil,
jalan Basuki Rahmat.

karakteristik masyarakat berupa adat/radisi. Kondisi tersebut diidentifikasi terdapat di koridor jalan koridor jalan Pahlawan, dan koridor Jalan Basuki Rahmat.

\section{DAFTAR PUSTAKA}

Athur Gallion (1994) Pengantar Perencanaan Kota, Airlangga.

Budihardjo, Eko (1994) Percikan Masalah Arsitektur, Perumahan dan Perkotaan, Alumni Bandung

Budihardjo, Eko (1991) Arsitektur dan kota di Indonesia, Alumni Bandung

Budihardjo, Eko (1994) Konservasi Lingkungan dan Bangunan Kuno Bersejarah di Surakarta, Gajah Mada University press

Catannesse Anthony J dan James Cz Snyder (1989) Urban Planning (Perencanaan kota) Erlangga Jakarta

Danisworo M, (1996) Konsep untuk Mewujudkan keselarasan antara pertumbuhan peremajaan dan konservasi dalam pembangunan kota.

Lynch Kevin (1981) Good City Form, The MIT Press, Cambrudge Massachusetts.

Lynch Kevin (1961) the image of the city, The MIT Press, Cambrudge Massachusetts

Moloeng Lexy J (2001), Metodologi Penelitian Kualitatif, Cetakan ke empatbelas PT remaja rosdakarya, Bandung

Rappoport Amos Human Aspect of Urban Form, Oxford Pergamon Press, 1980.

Sidharta dan Eko Budihardjo, Konservasi Lingkungan dan Bangunan Kuno Bersejarah di Surakarta, Gajah Mada University Press Yogyakarta, 1989

Suryabrata sumadi (1983) Metodologi Penelitian, Universitas Gajah Mada Yogyakarta

The Burra Charter for Conservation of place of cultural significance dalam Sidharta dan Eko Budihardjo, konservasi lingkungan dan bangunan kuno bersejarah di Surakarta, Gajah Mada Universitas press Yogyakarta 1989

Trancik roger Finding the Lost Space Van Nostrand Reindhold, co NY 1986

Zanh Markus (1999) Perancangan Kota secara terpadu, penerbit kanisius Semarang

Rencana Tata Ruang Kota Gresik tahun $2002-2007$

Ratniarsih I (2001) Perubahan Perumahan Kampung Arab di Gresik (dari sudut Tinjau Diskonstruksi) Thesis pasca sarjana arsitektur tidak diterbitkan Surabaya jurusan Teknik Arsitektur ITS

Kwanda Timocin (2004) Desain bangunan baru pada kawasan pelestarian di Surabaya, Jurnal dimensi teknik arsitektur vol 32 no 2 Desember 2004; 102 - 109 
Pratomo Andri S, et All (2006) Pelestarian Kawasan kampong batik laweyan kota Surakarta dimensi teknik arsitektur vol 34 no 2 Desember 200693 - 105

Risbiyanto Ervin et All (2008) pelestarian kampong Arab Malik Ibrahim di Kota Gresik, Jurnal Arsitektur e-journal volume 1 nomor 1 Maret 2008. 